\title{
KEBIJAKAN ALI IBN ABI THALIB DALAM IJTIHAD
}

\author{
Mhd. Rasidin \\ Institut Agama Islam Negeri Kerinci \\ J1. Pelita IV Sungai Penuh, Sumur Gedang, Kabupaten Kerinci, Jambi \\ Pos-el: mhd_rasidin@yahoo.co.id \\ Doli Witro \\ Institut Agama Islam Negeri Kerinci \\ Jalan Pelita IV Sungai Penuh, Sumur Gedang, Kabupaten Kerinci, Jambi \\ Pos-el: doliwitro01@yahoo.com
}

\author{
Imaro Sidqi \\ Institut Agama Islam Negeri Pekalongan \\ J1. Kusuma Bangsa No. 9, Panjang Baru, Pekalongan Utara, Kota Pekalongan, Jawa Tengah \\ Pos-el: imarosidqi@gmail.com
}

\begin{abstract}
Historically, one of the reasons for Islam's growth and development in various parts of the world is the nature of Islam that is never static in a law. In the context of these changes, the elasticity and flexibility of Islamic law in responding to the problems of human life are increasingly demanded and expected to be able to accommodate them. One way is to do ijtihad to determine the law of every new problem that arises. Evidenced since the time of the Prophet s.a.w., the practice of ijtihad is always done by friends when they cannot ask directly to the Prophet s.a.w. One of the best-known friends did ijtihad after Rasulullah s.a.w. died is Ali ibn Abi Talib. Starting from this description, the writer wants to see Ali ibn Abi Talib's policy of ijtihad. This paper uses qualitative research methods that are library research. The data in this paper is sourced from books, journals, articles discussing Ali ibn Abi Talib, and ijtihad. After the data is collected, it is then analyzed and analyzed with data analysis techniques, namely data reduction, data presentation, and conclusion drawing. The analysis shows that in the Ali ibn Abi Talib's ijtihad has its patterns and methods in istinbath or establishing Islamic law (fiqh). His determination to hold on to the verses of the Al-Quran as a whole and his carefulness to judge a Sunah, as well as his flexibility in using the $r a^{\prime} y u$ (reason) was a distinctive feature for Ali ibn Abi Talib in dealing with the legal polemic that occurred in the society at that time.
\end{abstract}

Keywords: Ali ibn Abi Thalib; Ijtihad; Policy

\begin{abstract}
Abstrak: Secara historis, salah satu sebab Islam tumbuh dan berkembang di berbagai belahan dunia, adalah sifat Islam yang tidak pernah statis pada sebuah hukum. Pada konteks perubahan tersebut, elastisitas dan fleksibelitas hukum Islam dalam menjawab problematika kehidupan manusia semakin dituntut dan diharapkan untuk bisa mengakomodasinya. Salah satu caranya yaitu dengan melakukan ijtihad untuk menentukan hukum setiap permasalahan baru yang muncul. Terbukti sejak masa Nabi s.a.w., praktek ijtihad senantiasa dilakukan oleh para sahabat ketika tidak dapat menanyakan secara langsung kepada Nabi s.a.w. Satu di antara sahabat yang terkenal melakukan ijtihad setelah Rasulullah s.a.w. wafat ialah Ali ibn Abi Thalib. Berangkat dari uraian inipenulis hendak melihat kebijakan Ali ibn Abi Thalib mengenai ijtihad. Tulisan ini menggunakan metode penelitian kualitatif yang bersifat library research. Data-data dalam tulisan ini bersumber dari buku-buku, jurnal-jurnal, artikel-artikel yang membahas Ali ibn Abi Thalib dan ijtihad. Setelah data terkumpulkan kemudian ditelaah dan dianalisis dengan teknik analisis data yaitu reduksi data, penyajian data, dan penarikan kesimpulan. Hasil analisa menunjukkan bahwa dalam berijtihad Ali ibn Abi Thalib memiliki pola dan metode tersendiri dalam istinbath atau menetapkan hukum Islam (fiqih). Keteguhannya untuk berpegang pada ayat-ayat Al-Quran secara keseluruhan dan kehati-hatiannya untuk menilai suatu Sunah, serta keleluasaannya dalam menggunakan ra'yu (akal) merupakan ciri tersendiri bagi Ali ibn Abi Thalib dalam menghadapi polemik hukum yang terjadi di masyarakat kala itu.
\end{abstract}

Kata kunci: Ali ibn Abi Thalib; Ijtihad; Kebijakan 


\section{Pendahuluan}

Manusia merupakan makhluk sosial yang tidak mungkin dapat hidup seorang diri. Kebutuhan hidup yang bermacammacam membuat manusia selalu senantiasa berinteraksi dan membutuhkan orang lain. ${ }^{1}$ Oleh karena itu, dalam kehidupan bermasyarakat, diperlukan segenap hukum yang mengatur antara individu dengan individu yang lainnya. Namun, ketika eksistensi hukum tersebut sudah mulai memudar dan tidak diakui oleh sebagian anggota masyarakat, maka diperlukan reaktualisasi dari hukum tersebut.

Istilah reaktualisasi dalam hukum Islam merupakan sebuah diskursus yang selalu dibicarakan di mana-mana, terutama di kalangan ahli fiqih. Secara sederhana istilah ini mengarah pada pengejewantahan ajaran Islam dengan melakukan interpretasi terhadap kedua sumbernya yakni Al-Quran dan Sunah. Kedua sumber tersebut dijadikan sebagai dasar bangunan dan sumber syariat Islam. Menurut Fathi al-Duraini, Al-Quran dan Sunah disebut al-nushush al-muqaddasah yang diturunkan Allah s.w.t. dalam bentuk

1 Wahyu Abdul Jafar, "Imamah dalam Perspektif Kemaslahatan Rakyat", Al-Imarah: Jurnal Pemerintahan dan Politik Islam, Vol. 2, No. 1, 2017, h. 60. Lihat juga, Doli Witro, "Praktek Jual Beli Parang dengan Cara Penumpukan untuk Meningkatkan Harga di Desa Koto Padang Perspektif Hukum Islam", Al-Qisthu, Vol.17, No.1, 2019, h. 34 wahyu yang terjauh dari intervensi akal dan rasio manusia. Oleh karena itu, apabila telah dilakukan pemahaman yang mendalam dan ijtihad terhadap maknamakna yang dikandungnya, illat-illat, serta tujuan-tujuannya, maka al-nushhush almuqaddasah (nash-nash Al-Quran dan Sunah) tersebut menjadi fiqih yang senantiasa dapat berubah seiring dengan perubahan masa dan tempat. ${ }^{2}$

Terbukti secara historis sepanjang sejarah bahwa salah satu sebab Islam tumbuh dan berkembang di berbagai belahan dunia, adalah oleh sifat Islam itu sendiri yang tidak pernah statis pada sebuah hukum. Hukum pada suatu masa dan tempat tertentu yang dihasilkan oleh orang (Mujtahid) tertentu, dapat berlainan, bahkan bertolak belakang, dengan kesimpulan orang (Mujtahid) lain pada masa dan tempat yang lain. ${ }^{3}$

Pada konteks perubahan tersebut, elastisitas dan fleksibelitas hukum Islam dalam menjawab problematika kehidupan manusia semakin dituntut dan diharapkan untuk bisa mengakomodasinya. Dalam

2 Muhammad Fathi al-Dhuraini, Buhusu Muqaranah fi al-Figh al-Islami wa Ushulih, (Beirut: Muassasah, 1994), Juz 1, h. 16.

3 Sya'ban Mauluddin, "Karakteristik Hukum Islam (Konsep Dan Implementasinya)", Jurnal Ilmiah Al-Syir'ah, Vol. 2, No. 1, 2004, h. 9. Bandingkan dengan Roseffendi, "Hubungan Korelatif Hukum Dan Masyarakat Ditinjau Dari Perspektif Sosiologi Hukum”, Al-Imarah: Jurnal Pemerintahan dan Politik Islam, Vol. 3, No. 2, 2018, h. 190. 
bentuk inilah, begitu pentingnya arti sebuah reaktualisasi hukum Islam dalam rangka mewujudkan agama Islam yang bersifat rahmatan lil 'alamin. Senada dengan yang diungkapkan oleh ibn Qayyim al-Jauziah berubah dan berbedanya fatwa sesuai dengan perubahan zaman, tempat, kondisi sosial, niat, dan adat kebiasaan. ${ }^{4}$

Kaidah yang di atas menunjukkan fatwa dapat saja berubah tergantung situasi, kondisi, zaman, sosial, dan kebiasaan suatu masyara'at. Perubahan fatwa tersebut tentunya harus berdasarkan pada tujuan dan dasar syariat Islam yang mengutamakan keadilan dan kemaslahatan. Oleh karena itu, dapat dikatakan bahwa yang didukung dan sejalan dengan nash-lah yang disebut maslahah dalam Islam. ${ }^{5}$

Al-Syatibi menjelaskan pada dasarnya penetapan hukum syara' tidak untuk kebaikan umat muslim dalam mengarungi hidup di dunia dan akhirat. ${ }^{6}$ Ungkapan dan pandangan terhadap tujuan-tujuan syara' tersebut pada akhirnya menjadi kajian yang menarik dikalangan pakar ushul fiqih

4 Ibn Qayyim al-Jauziyah, I'lam almuwaqqi'in an Rabb al-Alamin, (Beirut: Dar-alFikr, 1997), Juz 3, h. 14.

${ }^{5}$ Wahbah al-Zuhayli, Ushul al-Fiqh al-Islami, (Damaskus: Dar al-Fikr, 1986), Juz 2, h. 752-754. Lihat juga, Nasrun Haroen, Ushul Fiqh I, (Jakarta: Logos Wacana Ilmu, 1997), h. 117.

${ }^{6}$ Abu Ishaq al-Syatibi, al-Muwafaqat fi Ushul al-Syari'ah, (Beirut: Dar al-Kutub al-Ilmiyah t.th.), Juz 2, h. 3-4. belakangan. Menurut Yusuf al-Qaradhawi, semua ketetapan hukum syara' yang ditetapkan oleh para ulama tentunya memiliki tujuan dan alasan tertentu. Sehingga dari semua itu harus diwujudkan dan dilaksanakan oleh setiap muslim. Sebab Allah sebagai pembuat syari'at lebih mengetahui makna yang terkandung di dalam wahyu-Nya. ${ }^{7}$

Pemahaman terhadap tujuan-tujuan syara' dalam kajian ushul fiqih lebih lanjut berkembang dengan istilah maqashid alsyariah. Pemahaman terhadap maqashid al-syariah memiliki peranan yang sangat signifikan dalam berijtihad. Ijtihad adalah salah satu hal yang menjadi jalan dalam memahami ayat-ayat hukum untuk menjadikan norma hukum baru(fiqh). ${ }^{8}$ Ada juga yang mengatakan kalau ijtihad adalah pencurahan segala kemampuan secara maksimal untuk memperoleh suatu hukum syara' yang amali melalui penggunaan sumber syara' yang diakui yaitu Al-Qur'an dan Hadis. ${ }^{9}$ Ijtihad mempunyai peranan yang sangat strategis dalam menjawab

${ }^{7}$ Yusuf al-Qaradhawi, Fiqh Prioritas, Sebuah Kajian Baru Berdasarkan Al-Qur'an dan Sunnah, (Penerjemah) Baharuddin F., Judul Asli Fi Fiqh alAuliyat wa Dirasah Jadidah fi Dhu' al-Qur'an wa Sunnah, (Jakarta: Robbani Press, 1996), h. 36.

${ }^{8}$ Khoirul Hadi, "Hukum Ijtihad dalam Proses Legislasi Hukum Islam, Isti'dal; Jurnal Studi Hukum Islam, Vol. 1, No. 2, 2014, h. 182.

${ }^{9}$ Fauzi M, "Urgensi Ijtihad Saintifik Dalam Menjawab Problematika Hukum Transaksi Kontemporer", Nalar Fiqh: Jurnal Kajian Ekonomi Islam dan Kemasyarakatan, Vol. 4, No. 2, 2011, h. 22. 
permasalahan-permasalahan agama.

Terbukti sejak masa Nabi s.a.w., praktek ijtihad senantiasa dilakukan oleh para sahabat ketika tidak dapat menanyakan secara langsung kepada Nabi s.a.w. Namun tidak semua sahabat dapat melakukan ijtihad, melainkan hanyalah beberapa sahabat tertentu saja yang telah diakui oleh sahabat lainnya (umat Islam waktu itu) atau secara inplisit yang telah mendapat pengakuan oleh Nabi Muhammad s.a.w.

Satu di antara sahabat yang terkenal melakukan ijtihad setelah Rasulullah s.a.w. wafat ialah Ali ibn Abi Thalib. Ijtihad yang dilakukannya terhadap persoalan hukum telah mendapat pengakuan dari sahabat lainnya begitupun ulama masa kini, sehingga membuat Ali ibn Abi Thalib menjadi "ulama" besar pada era sahabat dan ahli fikir terutama pada zamannya. Bahkan beberapa para sahabat di dalam menghadapi suatu persoalan agama yang pelik tidak pernah memutuskannya kecuali setelah meminta pendapat dari Ali ibn Abi Thalib.

Berangkat dari uraian di atas penulis hendak melihat kebijakan Ali ibn Abi Thalib dalam ijtihad. Hal ini sangat menarik untuk dijadikan objek kajian serta dibahas dengan menganalisa satu di antara kasus ijtihadnya yang melahirkan fatwa hukum yang terkadang berbeda dengan sahabat lain. Sosok dan profil Ali ibn Abi Thalib yang dimunculkan dalam tulisan ini tidak ada tendensi dan maksud tertentu untuk merendahkan keberadaan sahabat lainnya.

\section{Metode Penelitian}

Tulisan ini menggunakan metode penelitian kualitatif yang bersifat library research. Data-data dalam tulisan ini bersumber dari buku-buku, jurnal-jurnal, artikel-artikel yang membahas Ali ibn Abi Thalib dan ijtihad. Data-data yang dikumpulkan kemudian dibaca, dipahami, dan diteliti. Data yang diperoleh dari literatur-literatur tersebut dikumpulkan kemudian diklasifikasikan dan diletakan pada posisi yang sesuai dengan sub judul yang ada pada sub poin pembahasan. Data tersebut kemudian ditelaah dan dianalisis dengan teknik analisis data yang dikenal oleh Miles dan Huberman yaitu "reduksi data, penyajian data, dan penarikan kesimpulan". ${ }^{10}$

10 Matthew B. Miles dan A. Michael Huberman, Qualitative Data Analysis (a Source book of New Methods), (Beverly Hills: Sage Publications, 1984), h. 21-24. 


\section{Hasil dan Pembahasan}

\section{Riwayat Hidup Ali ibn Abi Thalib}

Ali ibn Abi Thalib r.a. dilahirkan dekat Ka'bah pada 21 tahun sebelum Hijriah, atau tepatnya 30 tahun setelah kelahiran Rasulullah s.a.w. Pendapat lain mengatakan pada tahun ke-32 setelah kelahiran Rasulullah s.a.w.11 Ia adalah anak bungsu dari kedua orang tuanya, adapun nama-nama saudaura laki-lakinya yang lain adalah Ja'far, Uqail, dan Thalib. Ayahnya adalah paman Nabi s.a.w. yang bernama Abi Thalib ibn Abdul Muthalib ibn Hasyim ibn Abdi Manaf. Silsilah keturunan dari kedua orang tuanya ini menunjukkan bahwa Ali r.a. berdarah Hasyimi (Bani Hasyim).12

Nama lain dari Ali adalah Haidharah (nama yang dipilihkan ibunya), namun di tengah-tengah masyarakat nama "Ali" lah yang lebih terkenal. Sementara gelar yang disukai adalah Abu Thurab (bapak tanah), gelar yang diberikan oleh Nabi s.a.w. di samping gelar Abu Hasan yang lebih terkenal. ${ }^{13}$

${ }^{11}$ Majid Ali Khan, Sisi Hidup Para Khalifah Saleh, (Penerjemah), Joko S. Abd. Kahhar, Judul Asli, The Pious Chalips, (Surabaya: Risalah Gusti, 2002), h. 195

12 Jalaluddin al-Suyuthi, Tarikh al-Khulafa', (Beirut: Dar al-Fikr, t.th.), h. 155.

13 Shubhi Rajib al-Mahmasani, Turâts alKhulafâ' al-Râsyidîn fì al-Fiqh wa al-Qadhâ', (Beirut: Dar al-Ilmi li al-Mulayin, 1984), h. 56.
Ketika Ali mulai tumbuh sebagai anak-anak dalam umur enam tahun, kekeringan dan kesusahan melanda suku Quraisy. Karena pengaruh krisis ekonomi dalam keluarga Ali. Kemudian Nabi Muhammad s.a.w. menyarankan kepada kedua pamannya (Hamzah dan Abbas) untuk turut membantu meringankan beban hidup saudaranya (Abi Thalib) dengan menanggung biaya hidup dan mengasuh anak-anaknya. ${ }^{14}$ Ajakan Nabi Muhammad s.a.w. disambut baik oleh kedua pamannya itu. Mengetahui hal itu, Abi Thalib berkata kepada kedua saudaranya tersebut: "ambillah siapa yang kalian ingin, namun tinggalkanlah Aqil untuk tetap aku asuh”. Untuk itulah Abbas menanggung Thalib, Hamzah mengambil Ja'far, dan Nabi Muhammad s.a.w. mengambil Ali.

Setelah beberapa lama Ali bersama Nabi, pada usia yang hampir 10 tahun, mulailah Ali melihat adanya tanda-tanda keanehan pada diri Muhammad s.a.w. sekaligus menjadi pendorong keislamannya. Berawal dari tugas dia untuk membawakan dan menyediakan kebutuhan Nabi s.a.w. ketika Nabi s.a.w. berada di Gua Hira'. Ia sering mendatangi Gua Hira', saat Rasulullah sedang khusyuk merenung ke hadirat Allah dalam kesendirian, dan di saat segenap alam

\footnotetext{
${ }^{14}$ Ibid.
} 
sedang berkumpul dan berdialog dengan hatinya tentang rahasia-rahasia semesta.

Ali termasuk orang yang mula-mula masuk Islam dari golongan anak-anak, bahkan lebih dahulu dari Abu Bakar. Sebab waktu itu usianya baru mencapai sepuluh tahun. Menurut riwayat lain, waktu itu umurnya masih tujuh atau delapan tahun. Ada yang mengatakan bahwa ia menyatakan masuk Islam saat berada pada usia antara lima belas-enam belas tahun ${ }^{15}$. Keislaman Ali itu, juga perlu diketahui bahwa hatinya suci dari penyembahan berhala. Sebab ia terdidik langsung dari bimbingan Rasulullah s.a.w.

\section{Ali ibn Abi Thalib dalam istimbath}

\section{Hukum}

Secara umum dapat diketahui bahwa pada masa sahabat merupakan masa dimana syari'ah Islam menghadapi berbagai persoalan yang tidak didapati pada masa Rasulullah s.a.w. Berbagai kasus timbul yang menuntut kepastian hukum. Dalam hal ini, sahabat sangat dituntut untuk memainkan peranannya dalam memberikan jawaban-jawaban dan kepastian hukum.

Salah seorang sahabat Rasulullah s.a.w. yang juga turut andil dalam perkembangan fiqih di era sahabat adalah

15 Muhammad Ridha, al-Imam Ali ibn Albi Thalib Kara'nallah Wajhahu,(Beirut: Dar al-kutub Ilmiyah, t.th.), h. 10.
Ali ibn Abi Thalib, kepantasan dia menjadi seorang Mujtahid dan tokoh dalam bidang syari'ah telah mendapat pengakuan dari Nabi dan sahabat-sahabat lainnya. Sehingga ia merupakan salah seorang sahabat yang turut memberi pengaruh dan warna tersendiri dalam perkembangan fiqih Islam. Hal ini terbukti dari adanya fatwa-fatwa atau keputusan hukum Ali yang dipakai dan dianut oleh Mujtahid dan ulama dari berbagai mazhab yang ada.

Bila dilihat berbagai fatwa hukum dan ijtihad Ali secara umum dapat ditarik kesimpulan bagaimana sikap dan pendapat Ali terhadap berbagai sumber hukum yang ada di masa sahabat (Al-Quran, Sunah, Ijma', dan ra'yu/Qiyas) ${ }^{16}$ sehingga pada akhirnya menggambarkan metode ijtihad Ali dalam menetapkan dan istinbath hukum

\section{Sikap Ali ibn Abi Thalib terhadap Al-} Quran

Al-Quran sebagai pegangan dan pedoman utama dalam kehidupan muslim bila dihubungkan dengan penafsiran AlQuran, Ali termasuk sahabat yang banyak menafsirkan Al-Quran. Bahkan, ia termasuk ahli tafsir yang masyhur di antara sahabat, serta sahabat yang terbanyak

\footnotetext{
${ }^{16}$ Muhammad Abd al-Rahim Muhammad, alMadkal ila Fiqh Imam Ali r.a., (Kairo: Dar alHadist, 1988), h. 12.
} 
dalam meninggalkan tafsir ayat-ayat AlQuran di antara al-Khulafa al-Rasyidin. Hal ini antara lain didukung tidak terlalu cepatnya Ali disibukkan oleh masalahmasalah pemerintahan seperti pendahulupendahulunya, serta panjangnya umur beliau dalam memenuhi hajat kaum muslimin akan penafsiran Al-Quran. Ditambah lagi dengan kecerdasan dan kemampuan yang dimiliki oleh Ali dalam menangkap rahasia-rahasia bahasa AlQuran, serta banyaknya kesempatan beliau untuk menghadiri majelis-majelis Nabi sejak masa remajanya.

Dengan dukungan hafalan yang kuat dan penafsiran yang mendalam. Dari aspek hukum, Ali senantiasa pertama kali merujuk pada Al-Quran. Bahkan ia termasuk sahabat yang kuat pendirian dalam berpegang teguh pada ayat-ayat AlQuran secara keseluruhan dalam menetapkan setiap hukum dalam permasalahan-permasalahan fiqih. Keteguhan dan pemahaman yang mendalam untuk berpegang teguh pada AlQuran tersebut dapat dilihat fatwa-fatwa hukum yang dikeluarkannya dan berbagai kasus yang dihadapinya.

\section{Sikap Ali ibn Abi Thalib terhadap Sunah}

Perbedaan aktivitas dan kesempatan di kalangan sahabat untuk menghadiri majelis-majelis Rasulullah s.a.w. dalam rangka mendengarkan dan menerima hadis langsung dalam majelis Beliau, secara tidak langsung menyebabkan kesenjangan dan ketidaksamaan derajat di antara sahabat dalam mengetahui Sunah. Ada di antara mereka yang banyak dan luas pengetahuannya tentang Sunah Nabi s.a.w., ada yang sedang-sedang saja, bahkan ada pula yang sedikit sekali. Sehingga hal ini menimbulkan perbedaan pendapat di kalangan sahabat sendiri maupun Mujtahid dan ulama pada periode berikutnya.

Ali ibn Abi Thalib merupakan salah seorang sahabat yang sering menerima hadis dari Rasulullah s.a.w. Sikap dan komitmen yang mendalam pada diri Ali akhirnya terbentuk dengan sendirinya untuk senantiasa berpegang teguh pada Sunah Nabi s.a.w. Akan tetapi, di sisi lain, tidaklah semua riwayat yang berasal dari sahabat diterima begitu saja oleh Ali ia mempunyai metode tersendiri untuk menilai dan menerima riwayat-riwayat tersebut. Untuk itu dalam menilai atau meneliti suatu Sunah benar-benar datang dari Rasulullah s.a.w., Ali "mengangkat 
sumpah" terhadap mereka yang meriwayatkanya itu. ${ }^{17}$

Namun cara ini, tidaklah selamanya menjadi syarat mutlak bagi Ali dalam menerima suatu riwayat. Bila orang yang meriwayatkannya adalah orang yang sudah tidak diragukan lagi akan hafalan serta kejujurannya, maka Ali tidak meminta kepadanya untuk bersumpah, seperti yang dilakukanya pada Abu Bakar.

Dengan demikian, "mengangkat sumpah" dalam meriwayatkan sebuah Sunah datang dari Rasulullah s.a.w. hanyalah salah satu cara untuk meyakinkan Ali akan keshahihan untuk menerima suatu Sunah bila dirasa perlu, atau dengan kata lain adalah untuk menambah kepastian dan kesahihan suatu riwayat yang disampaikan kepadanya. Cara tersebut bukan didasari atas keraguan terhadap kejujuran dan kelurusan periwayatan sahabat lain, pilih kasih, curiga, saling mendustainya para sahabat satu sama lain dalam menerima suatu riwayat hadis yang tidak mereka dengar langsung dari Rasulullah s.a.w., atau didasari tidak bersumbernya dari keluarga Nabi s.a.w. Melainkan cara seperti ini menunjukkan kehati-hatian dan ketegasan

17 Muhammad Ajjaj' al-Khatib, Ushul alHadits ulumuhu wa Musthalahuhu, (Beirut: Dar alFikr, 1989), h. 60. Lihat juga, Munzier Suparta, Ilmu Hadits, (Jakarta: Raja Grafindo Persada, 2002), Cet. Ke-3, h. 81-82.
Ali untuk memastikan keshahihan suatu Sunah Rasulullah s.a.w. Adanya cara seperti ini, bukan bermaksud untuk berpaling dari Sunahnya atau untuk memperkecil riwayatnya.

\section{Sikap Ali dalam Ijtihad}

Ijtihad di era sahabat atau dikenal dengan isitilah penggunaan ra'yu (akal) oleh manusia, secara sederhana istilah tersebut dalam perspektif ushul fiqih dengan penggunaan akal fikiran dalam menetapkan hukum syara' terhadap kasuskasus yang tidak terdapat secara eksplisit dalam Al-Quran dan Sunah. Munculnya term ra'yu dengan disebabkan karena persoalan hukum semakin kompleks dan berkembang, wilayah Islam semakin luas, dan tingkat peradaban masyara'at semakin meningkat. Lebih lanjut, penggunaan ra'yu dalam teori ushul fiqih diformulasikan dalam bentuk lahirnya berbagai metode ijtihad sesuai dengan penekanan dan spesifikasinya masing-masing. Di samping juga didukung oleh teks-teks hukum yang terdapat dalam nash Al-Quran dan Sunah yang menuntut interpretasi-interpretasi lebih jauh.

Bagi Ali ibn Abi Thalib sendiri, penggunaan $r a^{\prime} y u$ dalam penetapan hukum merupakan bisa dikatakan suatu keharusan dalam menghadapi dan menyelesaikan persoalan hukum di tengah-tengah 
masyarakat. Sebab segala sesuatunya tidaklah dimuat secara eksplisit dalam nash-nash Al-Quran. Kadang Al-Qur'an hanya mengatur prinsip-prinsipnya saja dalam rangka mewujudkan kemaslahatan bagi umat manusia. Kebijakan Ali ini terbukti dari banyak keputusan hukum hasil ijtihadnya yang berdasarkan kepada penggunaan dan pemakain ra'yu dalam kasus-kasus fiqih yang dihadapinya, seperti kasus hukuman bagi peminum khamar. Namun demikian, penggunaan dan pemakaian ra'yu oleh Ali dalam istinbath hukum terhadap berbagai kasus fiqih yang dihadapinya tidak bebas begitu saja. Sebab dalam banyak riwayat, ia mengencam penggunaan ra'yu yang tidak bersandar kepada Al-Quran dan Sunah.

\section{Contoh Kebijakan Ali ibn Abi Thalib dalam Ijtihad}

Salah satu contoh ijtihad Ali ibn Abi Thalib yang masyur yaitu ketika ia memerintahkan untuk membakar suatu tempat atau perkampungan yang terkenal dengan perdagangan khamar di dalamnya.18 Berdasarkan sebuah riwayat, sebagaimana yang diungkapkan oleh Abu Ubaid dalam kitabnya al-Amwal bahwasanya Ali memandang (ke arah) suatu perkampungan yang bernama

${ }^{18}$ Muhammad Ruwas Qol'ah Jiy, Mausu'ah Fiqh Ali ibn Abi Thalib, (Beirut: Dar al-Nafais, 1996), Cet. Ke-1, h. 95 dan 98.
Zararah, kemudian ia bertanya: "kampung apa ini?" mereka (yang ada disekitarnya) menjawab: "ini sebuah perkampungan yang bernama Zararah, di situ khamar dikumpulkan dan diperjualbelikan”. Kemudian Ali bertanya lagi: "mana jalan untuk menuju kesana?" mereka menjawab : "Babul Jisri (Pintu Jembatan)", kemudian seseorang berkata: "wahai Amirul Mukminin, akan kami sediakan kapal air yang dapat membawamu ke tempat itu", Ali menjawab: "itu sama saja dengan menghina (manusia), kita tidak perlu menghina (sesama), mari kita berangkat ke Babul Jisri. Maka berjalanlah ia hingga sampai ke tempat yang dituju, lalu berkata: “cari api dan bakarlah tempat itu, karena sesungguhnya kejahatan saling memakan satu sama lain”.19 Menurut riwayat lain bahwa perkampungan itu terbakar dari kedua sisi baratnya hingga mencapai kebun khuwastabi Jabrauna.

Berdasarkan contoh diatas, tergambar bahwa Ali ibn Abi Thalib bisa dikatakan memiliki kebijakan tersendiri dalam ijtihadnya. Kebijakan tersebut menunjukan adanya kekhususan dan kejelian Ali ibn Abi Thalib dalam memandang suatu masalah hukum yang dihadapinya. Di samping itu terlihat juga bahwa Ali memiliki pola tersendiri dalam

\footnotetext{
${ }^{19}$ Abu Ubait al-Qasim ibn Salam, Kitab alAmwal, (Beirut: Dar al-Kutub al-Ilmiah, 1986), h. 105.
} 
Mhd. Rasidin, Doli Witro, dan Imaro Sidqi: Kebijakan Ali ibn Abi Thalib dalam Ijtihad

memandang kemaslahatan yang dituju oleh hukum yang difatwakannya, demi menjaga dan memelihara prinsip dan ruh syariat.

\section{Penutup}

Berdasarkan kajian dan uraian yang telah dipaparkan di atas dapat dipahami bahwa dalam berijtihad Ali ibn Abi Thalib memiliki pola dan metode tersendiri dalam istinbath atau menetapkan hukum Islam (fiqih). Keteguhannya untuk berpegang pada ayat-ayat Al-Quran secara keseluruhan dan kehati-hatiannya untuk menilai suatu Sunah, serta keleluasaannya dalam menggunakan ra'yu (akal) merupakan ciri tersendiri bagi Ali ibn Abi Thalib dalam menghadapi polemik hukum yang terjadi di masyarakat kala itu. Ijtihadijtihad yang telah dilakukan oleh Ali ibn Abi Thalib terhadap berbagai kasus hukum yang dihadapinya senantiasa menggali dan memahami secara mendalam tujuan hukum dan alasan penetapannya, serta mewujudkan kemaslahatn bagi manusia yang didukung oleh nash dan sejalan dengan ruh syariat.

\section{Pustaka Acuan}

al-Dhuraini, Muhammad Fathi, Buhusu Muqaranah fi al-Figh al-Islami wa Ushulih, Beirut: Muassasah, 1994, Juz 1.
al-Jauziyah, Ibn Qayyim, I'lam almuwaqqi'in an Rabb al-Alamin, Beirut: Dar-al-Fikr, 1997, Juz 3.

al-Khatib, Muhammad Ajjaj', Ushul alHadits ulumuhu wa Musthalahuhu, Beirut: Dar al-Fikr, 1989.

al-Mahmasani, Shubhi Rajib, Turâts alKhulafâ' al-Râsyidîn fì al-Fiqh wa alQadhâ', Beirut: Dar al-Ilmi li alMulayin, 1984.

al-Qaradhawi, Yusuf, Fiqh Prioritas, Sebuah Kajian Baru Berdasarkan AlQur'an dan Sunnah, (Penerjemah) Baharuddin F., Judul Asli Fi Fiqh alAuliyat wa Dirasah Jadidah fi Dhu' al-Qur'an wa Sunnah, Jakarta: Robbani Press, 1996.

al-Suyuthi, Jalaluddin, Tarikh al-Khulafa', Beirut: Dar al-Fikr, t.th.

al-Syatibi, Abu Ishaq, al-Muwafaqat $f i$ Ushul al-Syari'ah, Beirut: Dar alKutub al-Ilmiyah t.th., Juz 2.

al-Zuhayli, Wahbah, Ushul al-Figh alIslami, Damaskus: Dar al-Fikr, 1986, Juz 2.

Fauzi M, "Urgensi Ijtihad Saintifik Dalam Menjawab Problematika Hukum Transaksi Kontemporer”, Nalar Fiqh: 
Jurnal Kajian Ekonomi Islam dan Kemasyarakatan, Vol. 4, No. 2, 2011.

Hadi, Khoirul, "Hukum Ijtihad dalam Proses Legislasi Hukum Islam, Isti'dal; Jurnal Studi Hukum Islam, Vol. 1, No. 2, 2014.

Haroen, Nasrun, Ushul Fiqh I, Jakarta: Logos Wacana Ilmu, 1997.

Jafar, Wahyu Abdul, "Imamah dalam Perspektif Kemaslahatan Rakyat”, AlImarah: Jurnal Pemerintahan dan Politik Islam, Vol. 2, No. 1, 2017.

Jiy, Muhammad Ruwas Qol'ah, Mausu'ah Fiqh Ali ibn Abi Thalib, Beirut: Dar al-Nafais, 1996.

Khan, Majid Ali, Sisi Hidup Para Khalifah Saleh, (Penerjemah), Joko S. Abd. Kahhar, Judul Asli, The Pious Chalips, Surabaya: Risalah Gusti, 2002.

Mauluddin, Sya'ban, 'Karakteristik Hukum Islam (Konsep Dan Implementasinya)", Jurnal Ilmiah AlSyir'ah, Vol. 2, No. 1, 2004.

Miles, Matthew B. \& A. Michael Huberman, Qualitative Data Analysis (a Source book of New Methods), Beverly Hills: Sage Publications, 1984.
Muhammad, Muhammad Abd al-Rahim, al-Madkal ila Fiqh Imam Ali r.a., Kairo: Dar al-Hadist, 1988.

Ridha, Muhammad, al-Imam Ali ibn Albi Thalib Kara'nallah Wajhahu,Beirut: Dar al-kutub Ilmiyah, t.th.

Roseffendi, "Hubungan Korelatif Hukum Dan Masyarakat Ditinjau Dari Perspektif Sosiologi Hukum", AlImarah: Jurnal Pemerintahan dan Politik Islam, Vol. 3, No. 2, 2018.

Salam, Abu Ubait al-Qasim ibn, Kitab alAmwal, Beirut: Dar al-Kutub alIlmiah, 1986.

Suparta, Munzier, Ilmu Hadits, Jakarta: Raja Grafindo Persada, 2002.

Witro, Doli, "Praktek Jual Beli Parang dengan Cara Penumpukan untuk Meningkatkan Harga di Desa Koto Padang Perspektif Hukum Islam”, AlQisthu, Vol.17, No.1, 2019. 